\title{
PARTICIPANTS IN THE CONFERENCE
}

\author{
Roger A. Gorski, Co-Chairman and Editor \\ Department of Anatomy, UCLA School of Medicine \\ Los Angeles, California 90024 \\ Charles H. Sawyer, Co-Chairman and Editor \\ Department of Anatomy, UCLA School of Medicine \\ Los Angeles, California 90024
}

\author{
Yasumasa Arai \\ Department of Anatomy, Juntendo University School of Medicine \\ Hongo, Tokyo, Japan \\ Charles A. Barraclough \\ Department of Physiology, University of Maryland School of Medicine \\ Baltimore, Maryland 21201 \\ Frank A. Beach \\ Department of Psychology, University of California \\ Berkeley, California 94720 \\ Carlos Beyer \\ Departamento de Investigacion Cientifica \\ Apartado Postal 73-032 \\ Mexico 73, D. F. Mexico \\ KeITH Brown-Grant \\ Department of Human Anatomy, Oxford University \\ Oxford, England \\ LYNWOOD CLEMENS \\ Department of Zoology, Michigan State University \\ East Lansing, Michigan 48823 \\ VAUGHN CRITCHLOW \\ Department of Anatomy, Baylor University College of Medicine \\ Houston, Texas 77025
}




\author{
BARRY A. CROSS \\ Department of Anatomy, University of Bristol Medical School \\ Bristol, England \\ JULIAN DAVIDSON \\ Department of Physiology, Stanford University \\ Stanford, California 94305 \\ ELEMER ENDRóCZI \\ Medical Research, Post Graduate Medical School \\ Budapest, Hungary \\ JOHN W. EVERETT \\ Department of Anatomy, Duke University School of Medicine \\ Durham, North Carolina 27706
}

JACQUES FAURE

Chaire de Physiopathologie et Neurophysiologie

Faculte de Medecine et de Pharmacie

Pl. de la Victoire, Poste 84

Bordeaux, France

Shaul Feldman

Department of Neurology

Hadassah University Hospital

Jerusalem, Israel

Bela Flerkó

Anatomical Institute, University Medical School

Pécs, Hungary

W. F. GANONG

Department of Physiology, University of California

San Francisco, California 94122

\title{
ROBERT GOY
}

Oregon Regional Primate Research Center

Beaverton, Oregon 97006

JAMES N. HAYWARD

Department of Anatomy, UCLA School of Medicine

Los Angeles, California 90024

ROBERT I. HENKIN

National Institutes of Health

Bethesda, Maryland 20014 
GunNar Heuser

UCLA School of Medicine

Los Angeles, California 90024

JeSSAMINE Hilliard

Department of Anatomy, UCLA School of Medicine

Los Angeles, California 90024

MASAZUMI KaWAKAMI

Department of Physiology, Yokohama University

Urafune-Cho, Minami-Ku

Yokohama, Japan

BARRY KOMISARUK

Institute of Animal Behavior

Rutgers, The State University

Newark, New Jersey 07102

ROBERT D. LISK

Department of Biology, Princeton University

Princeton, New Jersey 08540

Luciano Martini

Department of Pharmacology, Universita Degli Studi 20129 Milano, Italy

S. M. MCCANN

Department of Physiology, University of Texas

Southwestern Medical School

Dallas, Texas 75235

BRUCE MCEWEN

The Rockefeller University

New York, New York 10021

Bengt J. Meyerson

Department of Pharmacology, University of Uppsala

Uppsala, Sweden

JoHn Money

Department of Psychiatry and Pediatrics

Johns Hopkins University

Baltimore, Maryland 21205

Preston L. Pearlman

Director of Biological Research

Schering Corporation

Bloomfield, New Jersey 07003 


\title{
Donald Pfaff
}

The Rockefeller University

New York, New York 10021

V. Domingo Ramírez

Department of Physiology, Austral University Valdivia, Chile

Felix A. SteIner

Department of Experimental Medicine

F. Hoffmann-LaRoche \& Co. Ltd.

4002 Basle, Switzerland

WALTER E. STUMPF

Laboratories for Reproductive Biology

University of North Carolina

Chapel Hill, North Carolina 27514

\author{
ANNA TAYLOR \\ Department of Anatomy, UCLA School of Medicine \\ Los Angeles, California 90024 \\ SAMUEL TALEISNIK \\ Instituto de Investigacion Medica \\ Mercedes y Martin Ferreyra \\ Cordoba, Argentina \\ ANTONIA VERNADAKIS \\ Department of Psychiatry \\ University of Colorado School of Medicine \\ Denver, Colorado 80220 \\ RichaRd E. WHALEN \\ Department of Psychobiology, University of California \\ Irvine, California 92664
}

